\title{
THE ROLE OF OPEN-AIR INHALATORIA IN THE AIR QUALITY IMPROVEMENT IN SPA TOWNS
}

\section{ALEKSANDRA BURKOWSKA-BUT, AGNIESZKA KALWASIŃSKA, and MARIA SWIONTEK BRZEZINSKA}

Nicolaus Copernicus University, Toruń, Poland

Departament of Environmental Microbiology and Biotechnology

\begin{abstract}
Objectives: The present study was aimed at evaluating microbiological contamination of air in Ciechocinek and Inowrocław - Polish lowland spa towns. Additionally, the impact of open-air inhalatoria on the quality of air was evaluated. Material and Methods: Air samples were collected seasonally in the urban areas, in the recreation areas and in the vicinity of inhalatoria in both towns using impaction. The numbers of mesophilic bacteria, staphylococci, hemolytic bacteria and actinomycetes were determined on media according to the Polish Standard PN-86/Z-04111/02. The number of moulds was determined on media according to the Polish Standard PN-86/Z-04111/03. Results: While the highest numbers of microorganisms were noted at the sites located in the urban areas, the lowest numbers were noted in the vicinity of the open-air inhalatoria. In all the investigated air samples the values of bioaerosol concentrations were below the recommended TLVs ( $\leq 5000 \mathrm{CFU} \times \mathrm{m}^{-3}$ for both bacteria and fungi in outdoor environments). Location of the sampling site was invariably a decisive factor in determining the number of microorganisms in the air. Conclusions: The aerosol which is formed in the open-air inhalatoria has a positive influence on microbiological air quality. Owing to a unique microclimate and low air contamination, Ciechocinek and Inowrocław comply with all necessary requirements set for health resorts specializing in treating upper respiratory tract infections.
\end{abstract}

Key words:

Health resort, Airborne microorganisms, Air quality, Spa towns

\section{INTRODUCTION}

Air, as one of the main components of the environment, has a great influence on human health. Within one day an average person inhales approximately 10 000-12 0001 $(12-14 \mathrm{~kg})$ of air along with various contaminants, which is many times more than the amount of water they drink or food they consume. In addition to industrial contaminants (gases and dust), air always contains microbiological contaminants, including viruses, bacteria and fungal spores present in the air in a form of aerosol [1-3].

Due to the negative impact of various microorganisms on the health of humans, animals and plants, microbiological air contamination has become an issue of growing concern $[4,5]$. It must be additionally accentuated that it is the airborne transmission that constitutes the fastest way of spreading microbial contaminants [3,6].

Apart from saprophytic microorganisms, air may also contain numerous pathogenic, allergenic and toxigenic microorganisms which pose a serious health risk for humans [3]. Since entry of infections in humans includes pulmonary airway, mouth, nose (nasal cavity) as well as pharynx, an infection can be caused by airborne germs attached to dust particles or present in droplets as bioaerosols (droplet infection) [7-9]. Microbiological air quality is of tremendous

Received: March 8, 2013. Accepted: March 19, 2014.

Corresponding author: A. Burkowska-But, Nicolaus Copernicus University, Departament of Environmental Microbiology and Biotechnology, Lwowska 1, 87-100 Torun, Poland (e-mail:wodkow@umk.pl). 
importance in spa towns, particularly in those which offer various types of respiratory diseases treatment [10,11]. Graduation towers - structures of blackthorn brushwood originally designed to increase concentration of salt in the saline solution (brine) - known to remarkably improve microbiological air quality, are currently used in spa towns as huge natural inhalatoria.

Graduation towers are unique objects, therefore information concerning their impact, especially in respect of environmental microbiology and public health, is not easily available in literature. Although they were built already in the 17th century, only few have remained in Europe, mainly in Poland and Germany. Graduation towers in Ciechocinek are the largest structures of this kind in $\mathrm{Eu}-$ rope and the oldest in Poland; the one in Inowrockaw is the second largest such a structure in Poland.

In view of the fact that Ciechocinek and Inowrocław are renowned spa towns specializing in respiratory diseases treatment (including upper respiratory tract infections, sinusitis, bronchiectasis, emphysema, chronic bronchitis and conditions resulting from pneumonia as well as bronchitis and chronic obstructive pulmonary disease - COPD), the present study aimed at evaluating microbiological air contamination in these places, with special emphasis on the air quality in the vicinity of the open-air inhalatoria.

\section{MATERIAL AND METHODS}

\section{Object of the study}

Ciechocinek, located in Kuyavia on the left bank of the

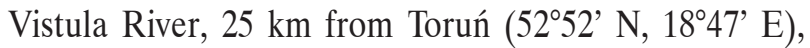
is the biggest Polish lowland spa, the sanatoria of which are visited annually by approximately 70000 people. Its glowing reputation as a spa town relies on the healing properties of local mineral springs and favourable climate conditions (high average yearly temperature, low humidity, low precipitation). This spa town is known to specialize in treating cardiovascular diseases, orthopedic and rheumatic disorders, nervous system disorders, and female reproductive system diseases. Moreover, the open-air inhalatoria (the graduation towers and the "Grzybek" (Mushroom)) fountain allow to treat a number of respiratory diseases including bronchitis and chronic inflammations of the pharynx, larynx, trachea, and Eustachian tube. Spectacular landscape and diversified plant life have also contributed to the town's status as a popular health resort.

Located in the Great Poland Lakeland (52 $47^{\prime}$ N, $\left.18^{\circ} 15^{\prime} \mathrm{E}\right)$, Inowrocław is one of the largest towns in the KuyaviaPomerania Province (population of about 77 600). The town, a major economic centre, with well-developed chemical, mechanical engineering, glass and graphic arts industries, is also the 2nd largest (after Ciechocinek) lowland spa in Poland. A wide range of spa treatments offered by the local sanatoria are based on natural resources such as chloride-sodium, bromide and magnesium brines leached from the local salt deposits, local bitter brine and peat mud. This spa town specializes in treating rheumatic, orthopedic, gastrointestinal and nervous disorders, cardiovascular diseases, and female reproductive system diseases. The graduation tower contributes greatly to the town's microclimate. The area in the immediate vicinity of the tower is separated from the urban area by an old park (established over a 100 years ago) [12-14].

\section{Sampling sites}

In the case of Ciechocinek air samples were collected at the 8 following sampling sites:

- in the urban area (3 sampling sites) - at the intersection of Kopernika street and Bema street, near the railway station in Kopernika street;

- in the recreation area (5 sampling sites) - near Dom Zdrojowy (in the Park Zdrojowy), and in the immediate vicinity of the open-air inhalatoria: near the "Grzybek" (Mushroom) fountain and near the graduation towers nr 1, 2 and 3. 
In the case of Inowrockaw air samples were collected at the 6 following sampling sites:

- in the urban area (2 sampling sites) - in Biskupa Antoniego Laubitza street and near the Municipal Office Building in Franklina D. Roosevelta street;

- in the recreation area (4 sampling sites) - in the Park Solankowy (2 sampling sites), and in the immediate vicinity of the graduation tower (2 sampling sites).

\section{Sampling}

Air samples were collected according to the Polish Standard PN-89/Z-04008/08 [15], $1.3 \mathrm{~m}$ above the ground level, seasonally from summer 2011 to spring 2012. The samples were obtained using impaction in the Merck MAS-100 microbial air sampler. The air flow velocity of $11 \mathrm{~m} / \mathrm{s}$ enabled detection of particles larger than $1 \mu \mathrm{m}$, i.e. those important for the translocation of microorganisms. Collection efficiency of MAS-100 (cut of size, or $d_{50}$ ) is $1.47 \mu \mathrm{m}-$ theoretical, and $1.7 \mu \mathrm{m}$ - experimental. Its use may result in underestimation of bacterial concentrations, especially of the single bacterial cells with diameter of $0.5-1 \mu \mathrm{m}$. On the other hand, MAS-100 is more efficient when collecting larger fungal spores [16].

Selected meteorological parameters including air temperature, relative humidity and wind speed were also measured using Nielsen-Kellerman Kestrel 3500 Pocket Wind Meter (Table 1).

\section{Microbiological tests}

Microbiological tests were aimed at determining the number of the following microbial groups:

- mesophilic bacteria - in accordance with the Polish Standard PN-89/Z-04111/02, the bacteria were cultured on PCA medium for $48 \mathrm{~h}$ at $37^{\circ} \mathrm{C}$ [17],

- mannitol positive staphylococci - in accordance with the Polish Standard PN-86/Z-04111/02, the bacteria were cultured on Chapman medium for $48 \mathrm{~h}$ at $37^{\circ} \mathrm{C}$ [17],

- hemolytic bacteria - in accordance with the Polish Standard PN-86/Z-04111/02, they were cultured on blood agar for $48 \mathrm{~h}$ at $37^{\circ} \mathrm{C}$ [17],

- actinomycetes - in accordance with the Polish Standard PN-86/Z-04111/02, the bacteria were cultured on Pochon medium for 5 days at $26^{\circ} \mathrm{C}$ [17],

- moulds - in accordance with the Polish Standard PN-86/Z-04111/03, they were cultured on Czapek-Dox medium for 5 days at $26^{\circ} \mathrm{C}$ [18].

All the tests were performed in triplicate in order to minimise errors resulting from random sampling. The results were calculated as colony forming units in $1 \mathrm{~m}^{3}\left(\mathrm{CFU} \times \mathrm{m}^{-3}\right)$ and subjected to statistical

Table 1. Meteorological parameters during sample collection

\begin{tabular}{clcccc}
\hline Spa town & \multicolumn{1}{c}{ Season } & $\begin{array}{c}\text { Temperature } \\
\left({ }^{\circ} \mathrm{C}\right) \\
{[\mathrm{M}(\text { (range })]}\end{array}$ & $\begin{array}{c}\text { Humidity } \\
(\%) \\
{[\mathrm{M}(\text { range })]}\end{array}$ & $\begin{array}{c}\text { Wind velocity } \\
(\mathrm{m} / \mathrm{s}) \\
{[\mathrm{M}(\mathrm{range})]}\end{array}$ & Others \\
\hline Ciechocinek & spring $(17.05 .2011)$ & $17.2(16.8-17.6)$ & $66.1(65.2-68.8)$ & $2.5(2.4-2.7)$ & \\
& summer $(6.09 .2011)$ & $18.8(18.4-19.20)$ & $68.2(65.3-70.1)$ & $2.6(2.4-2.9)$ & \\
& autumn $(24.10 .2011)$ & $8.6(7.2-8.9)$ & $70.3(69.1-73.2)$ & $1.1(0.8-1.5)$ & \\
& winter $(13.02 .2012)$ & $1.8(-0.3-2.5)$ & $59.6(56.8-61.0)$ & $3.8(2.9-4.1)$ & snow cover \\
Inowrocław & spring $(17.05 .2011)$ & $15.3(14.4-16.6)$ & $69.4(67.8-72.5)$ & $2.7(2.3-2.9)$ & \\
& summer $(4.09 .2011)$ & $20.7(19.9-21.2)$ & $65.1(63.4-68.4)$ & $3.7(2.7-4.0)$ & \\
& autumn $(24.10 .2011)$ & $10.1(8.5-11.1)$ & $65.8(61.9-67.8)$ & $1.1(0.8-1.7)$ & \\
& winter $(14.02 .2012)$ & $1.7(0.6-2.9)$ & $58.4(55.3-60.8)$ & $4.5(3.3-5.1)$ & \\
\hline
\end{tabular}

M-mean. 
analysis using Statistica 6.0 software. Concentrations of airborne microorganisms in the lowland spa towns depending on research series (seasons) and sampling sites were characterized using arithmetic means and range of values. The 2-way ANOVA analysis was used to determine effects of seasons and sites of sampling on the level of microbial aerosol. Results were considered statistically significant if $\mathrm{p}$ value was smaller than $0.05(\mathrm{p}<0.05)$.

\section{RESULTS}

In both towns, the highest average numbers of microorganisms in all microbial groups were noted at the sites located in the urban areas. The lowest average numbers were noted in the vicinity of the open-air inhalatoria (Table 2). These differences were statistically significant $(\mathrm{p}<0.05)$. All air samples (i.e., collected in both towns, in all seasons) may be classified as uncontaminated with mesophilic bacteria (Table 3).

Air samples from the majority of sampling sites were moderately contaminated with hemolytic bacteria $(62.5-100 \%$ of all the tested samples). However, in the vicinity of the open-air inhalatoria in Inowrockaw the majority of samples $(71 \%)$ were uncontaminated with it. On the other hand, $12.5 \%$ of all the samples collected in the recreation area of Ciechocinek were heavily contaminated with hemolytic bacteria.

The air samples collected in Ciechocinek and Inowrockaw did not indicate high contamination with actinomycetes: the vast majority of air samples collected in the urban and recreation areas in Ciechocinek were moderately contaminated with actinomycetes (75\% and $62.5 \%$, respectively) compared to $50 \%$ of air samples collected in the vicinity of the open-air inhalatoria, which were uncontaminated. The majority of air samples collected in the urban and recreation areas in Inowrockaw were moderately contaminated with actinomycetes (62.5\% and 50\%, respectively), while the majority of air samples collected in the vicinity of the open-air inhalatoria were uncontaminated $(71 \%$ of the samples).

According to the Polish Standard PN-86/Z-04111/03 [18], all the air samples collected in Ciechocinek were uncontaminated with moulds compared to $25 \%$ of the air samples from the urban and recreation areas in Inowrocław, which were moderately contaminated. The remaining air

Table 2. Concentrations of airborne microorganisms in Ciechocinek and Inowrocław

\begin{tabular}{|c|c|c|c|c|c|c|}
\hline \multirow[t]{2}{*}{ Spa town } & \multicolumn{6}{|c|}{$\begin{array}{c}\text { Concentration } \\
\left(\mathrm{CFU} \times \mathrm{m}^{-3}\right) \\
{[\mathrm{M}(\text { range })]}\end{array}$} \\
\hline & $\begin{array}{l}\text { mesophilic } \\
\text { bacteria }\end{array}$ & $\begin{array}{c}\text { mannitol positive } \\
\text { staphylococci }\end{array}$ & $\begin{array}{c}\alpha \text {-hemolytic } \\
\text { bacteria }\end{array}$ & $\begin{array}{c}\beta \text {-hemolytic } \\
\text { bacteria }\end{array}$ & actinomycetes & moulds \\
\hline \multicolumn{7}{|l|}{ Ciechocinek } \\
\hline urban areas & $241(80-480)$ & $40(5-120)$ & $14(5-20)$ & $6(0-15)$ & $32(15-90)$ & $821(10-1500)$ \\
\hline recreation areas & $126(50-280)$ & $14(0-55)$ & $12(0-25)$ & $4(0-10)$ & $24(5-32)$ & $761(30-1450)$ \\
\hline vicinity of inhalatoria & $89(40-150)$ & $10(0-20)$ & $6(0-15)$ & $3(0-15)$ & $9(0-20)$ & $651(20-1350)$ \\
\hline \multicolumn{7}{|l|}{ Inowrocław } \\
\hline urban areas & $275(30-620)$ & $33(5-70)$ & $11(0-20)$ & $13(0-35)$ & $16(0-35)$ & $1614(290-4010)$ \\
\hline recreation areas & $134(30-240)$ & $12(5-25)$ & $11(5-25)$ & $9(0-30)$ & $14(5-16)$ & $1476(170-4350)$ \\
\hline vicinity of inhalatoria & $97(40-160)$ & $8(5-10)$ & $6(0-20)$ & $1(0-5)$ & $13(0-30)$ & $1258(250-2800)$ \\
\hline
\end{tabular}

M-mean. 
Table 3. Evaluation of air quality in the health resorts according to the Polish Standard PN-89/Z-04111/02 for the outdoor air [17]

\begin{tabular}{|c|c|c|c|c|c|c|c|c|}
\hline \multirow{2}{*}{ Group of microbes } & \multirow{2}{*}{$\begin{array}{l}\text { Range of values } \\
\left(\mathrm{CFU} \times \mathrm{m}^{-3}\right)\end{array}$} & \multirow{2}{*}{$\begin{array}{c}\text { Pollution } \\
\text { degree }\end{array}$} & \multicolumn{3}{|c|}{$\begin{array}{c}\text { Ciechocinek } \\
(\%)\end{array}$} & \multicolumn{3}{|c|}{$\begin{array}{c}\text { Inowrockaw } \\
(\%)\end{array}$} \\
\hline & & & $\begin{array}{c}\text { urban } \\
\text { areas }\end{array}$ & $\begin{array}{c}\text { recreation } \\
\text { areas }\end{array}$ & $\begin{array}{l}\text { vicinity of } \\
\text { inhalatoria }\end{array}$ & $\begin{array}{l}\text { urban } \\
\text { areas }\end{array}$ & $\begin{array}{c}\text { recreation } \\
\text { areas }\end{array}$ & $\begin{array}{l}\text { vicinity of } \\
\text { inhalatoria }\end{array}$ \\
\hline \multirow[t]{3}{*}{ Mesophilic bacteria } & $<1000$ & not polluted & 100.0 & 100.0 & 100.0 & 100.0 & 100.0 & 100.0 \\
\hline & $1000-3000$ & medium & 0 & 0 & 0 & 0 & 0 & 0 \\
\hline & $>3000$ & heavy & 0 & 0 & 0 & 0 & 0 & 0 \\
\hline \multirow[t]{3}{*}{$\alpha$-hemolytic bacteria } & absent & not polluted & 0 & 25.0 & 8.3 & 12.5 & 0 & 29.0 \\
\hline & $<25$ & medium & 100.0 & 62.5 & 91.7 & 87.5 & 100.0 & 71.0 \\
\hline & $>25$ & heavy & 0 & 12.2 & 0 & 0 & 0 & 0 \\
\hline \multirow[t]{3}{*}{$\beta$-hemolytic bacteria } & absent & not polluted & 37.5 & 37.5 & 50.0 & 12.5 & 36.2 & 71.0 \\
\hline & $<50$ & medium & 62.5 & 62.5 & 50.0 & 87.5 & 63.8 & 29.0 \\
\hline & $>50$ & heavy & 0 & 0 & 0 & 0 & 0 & 0 \\
\hline \multirow[t]{3}{*}{ Actinomycetes } & $<10$ & not polluted & 25.0 & 25.0 & 37.5 & 37.5 & 50.0 & 71.0 \\
\hline & $10-100$ & medium & 75.0 & 75.0 & 62.5 & 62.5 & 50.0 & 29.0 \\
\hline & $>100$ & heavy & 0 & 0 & 0 & 0 & 0 & 0 \\
\hline
\end{tabular}

Table 4. Evaluation of air quality in the health resorts according to the Polish Standard PN-89/Z-04111/03 for the outdoor air [18]

\begin{tabular}{|c|c|c|c|c|c|c|c|}
\hline \multirow{2}{*}{ 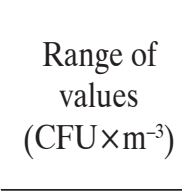 } & \multirow{2}{*}{ Pollution degree } & \multicolumn{3}{|c|}{$\begin{array}{c}\text { Ciechocinek } \\
(\%)\end{array}$} & \multicolumn{3}{|c|}{$\begin{array}{c}\text { Inowrocław } \\
(\%)\end{array}$} \\
\hline & & $\begin{array}{r}\text { urban } \\
\text { areas }\end{array}$ & $\begin{array}{l}\text { recreation } \\
\text { areas }\end{array}$ & $\begin{array}{l}\text { vicinity of } \\
\text { inhalatoria }\end{array}$ & $\begin{array}{l}\text { urban } \\
\text { areas }\end{array}$ & $\begin{array}{l}\text { recreation } \\
\text { areas }\end{array}$ & $\begin{array}{l}\text { vicinity of } \\
\text { inhalatoria }\end{array}$ \\
\hline$<3000$ & clean & 100 & 100 & 100 & 75 & 75 & 100 \\
\hline $3000-5000$ & relatively clean & 0 & 0 & 0 & 25 & 25 & 0 \\
\hline $5000-10000$ & $\begin{array}{l}\text { negative impact on environment } \\
\text { of human }\end{array}$ & 0 & 0 & 0 & 0 & 0 & 0 \\
\hline > 10000 & $\begin{array}{l}\text { threatening of human } \\
\text { environment }\end{array}$ & 0 & 0 & 0 & 0 & 0 & 0 \\
\hline
\end{tabular}

samples from Inowrocław, including those collected in the vicinity of the inhalatoria, may be classified as uncontaminated with moulds (Table 4).

The analysis of variance (ANOVA) indicated that the number of bacteria from the majority of bacterial groups depended on the location of the sampling site, while the number of moulds depended on the season (Table 5). Additionally, in Ciechocinek there was a positive correlation between the number of moulds and the temperature $(\mathrm{r}=0.88)$ and between actinomycetes and the temperature $(\mathrm{r}=0.36)$. In Inowrocław there was a positive correlation between the number of moulds and the temperature $(r=0.72)$, and between the number of mesophilic bacteria and the temperature $(r=0.44)$. All correlation coefficients were statistically significant $(\mathrm{p}<0.05)$. 
Table 5. Analysis of variance (ANOVA) of bacterial concentrations in the air of health resorts according to the location of the research sites and sampling season

\begin{tabular}{|c|c|c|c|c|}
\hline Spa town & Microorganisms & Factor & $\mathrm{F}$ & $\mathrm{p}$ \\
\hline \multirow[t]{12}{*}{ Ciechocinek } & \multirow[t]{2}{*}{ mesophilic bacteria } & site & 9.00 & 0.001 \\
\hline & & season & 2.71 & 0.065 \\
\hline & \multirow{2}{*}{$\begin{array}{l}\text { mannitolo positive } \\
\text { staphylococci }\end{array}$} & site & 5.29 & 0.011 \\
\hline & & season & 1.85 & 0.162 \\
\hline & \multirow[t]{2}{*}{$\alpha$-hemolytic bacteria } & site & 3.51 & 0.044 \\
\hline & & season & 0.74 & 0.537 \\
\hline & \multirow[t]{2}{*}{$\beta$-hemolytic bacteria } & site & 0.85 & 0.436 \\
\hline & & season & 1.08 & 0.371 \\
\hline & \multirow[t]{2}{*}{ actinomycetes } & site & 8.24 & 0.005 \\
\hline & & season & 31.85 & 0.000 \\
\hline & \multirow[t]{2}{*}{ moulds } & site & 1.18 & 0.321 \\
\hline & & season & 24.66 & 0.000 \\
\hline \multirow[t]{12}{*}{ Inowrocław } & \multirow[t]{2}{*}{ mesophilic bacteria } & site & 7.56 & 0.020 \\
\hline & & season & 4.23 & 0.004 \\
\hline & \multirow{2}{*}{$\begin{array}{l}\text { mannitolo positive } \\
\text { staphylococci }\end{array}$} & site & 9.17 & 0.001 \\
\hline & & season & 0.77 & 0.524 \\
\hline & \multirow[t]{2}{*}{$\alpha$-hemolytic bacteria } & site & 1.00 & 0.385 \\
\hline & & season & 1.03 & 0.403 \\
\hline & \multirow[t]{2}{*}{$\beta$-hemolytic bacteria } & site & 4.52 & 0.026 \\
\hline & & season & 1.89 & 0.174 \\
\hline & \multirow[t]{2}{*}{ actinomycetes } & site & 0.13 & 0.870 \\
\hline & & season & 5.21 & 0.036 \\
\hline & \multirow[t]{2}{*}{ moulds } & site & 3.09 & 0.071 \\
\hline & & season & 72.33 & 0.000 \\
\hline
\end{tabular}

F - among - groups variance / within - groups variance.

\section{DISCUSSION}

Natural therapies such as balneotherapy, hydrotherapy or climatotherapy help and complement conventional medicine. In Poland, approximately 350000 patients receive natural spa treatments in 43 spas, primarily oriented towards: treating, preventing and rehabilitating chronic illnesses [19]. Physiotherapy and prevention offered by spas may greatly contribute to the treatment of the upper respiratory tract infections (asthma, COPD, chronic voice disorder), which are currently a major social issue.

Since pulmonary rehabilitation emphasises the importance of outdoor activity, air in health resorts, especially in the case of patients suffering from respiratory diseases, should be of high quality. No major sources of air pollution should be located in the immediate vicinity of the resort treatment places $[10,11,20]$. According to the Act of 28 July 2005 on spa health care, health resorts and areas of spa conservation, a spa municipality is obliged to contribute to maintaining its unique properties, including meeting air quality standards [21].

Due to different environmental requirements of pathogenic microorganisms it is difficult to select one effective method to eliminate unwanted microorganisms from the air [22]. Graduation towers have been gaining popularity as an effective method of improving microbiological air quality. In recent years new structures were built in Inowrocław (2001), Busko-Zdrój (2008) and Rabka (2009) and the one in Gołdap was completed in 2013. The results presented in the study confirm the positive impact of graduation towers on microbiological air quality. Significantly higher numbers of mesophilic bacteria were noted in the urban areas than in the vicinity of the open-air inhalatoria. Similar results have been previously obtained by Burkowska and Donderski [23,24], Burkowska et al. [25] in Ciechocinek, and by Burkowska and Donderski [26] in Inowrocław.

Saline aerosol formed in graduation towers reduces the number of microoganisms in the air in their vicinity. Saline droplets accelerate the sedimentation of impurities present in the air, including microbial cells [27]. Furthermore, apart from $\mathrm{Cl}^{-}$and $\mathrm{Na}^{+}$ions saline aerosol contains $\mathrm{F}^{+}$, $\mathrm{Br}^{+}, \mathrm{J}^{+}$and $\mathrm{B}^{+}$ions, which considerably enhance its bactericidal properties [28]. The research conducted in subterraneotherapy chambers in Bochnia and Wieliczka $[29,30]$ and inhalation chamber in Szczawnica [31] have confirmed the role of saline aerosol in improving air quality. 
The results obtained by Walczak et al. [32] indicate a substantial reduction in the number of $E$. coli and $S$. aureus bacteria incubated in the brines from Ciechocinek.

The above results indicate that certain characteristic features typical of spa towns (no industry, no dense housing, large green areas) have a beneficial effect on the microbial air quality in Ciechocinek. Average numbers of the main microbial groups (mesophilic bacteria and moulds) were lower in Ciechocinek than they were in Inowrocław. Also in other typical spa town, a low air pollution with bioaerosol is usually recorded [30,31]. Fang et al. [33] have revealed that microbiological air contamination correlates with the population density and economic activity, and is therefore higher in urban than in rural areas [34].

As it was shown, the air in both spa towns, even in their urban areas, may be classified as uncontaminated compared to the air in large, densely populated urban agglomerations. In all the investigated air samples the values of bioaerosol concentrations were below the recommended TLVs, which is $5000 \mathrm{CFU} \times \mathrm{m}^{-3}$ for both bacteria and fungi in outdoor environments [35]. For example, Abdel Hameed et al. [36] have noted $1800 \mathrm{CFU} \times \mathrm{m}^{-3}$ of bacteria in Wadi Hof near Cairo, Filipiak et al. [37] as well as Bugajny et al. [38] have noted $13000 \mathrm{CFU} \times \mathrm{m}^{-3}$ of mesophilic bacteria in Poznań in the summer, while Fang et al. [33] have noted up to $22000 \mathrm{CFU} \times \mathrm{m}^{-3}$ of mesophilic bacteria in Beijing in the areas of high population density and heavy traffic. Bioaerosol in urban areas may contain as many as 1800 bacterial species, including those pathogenic ones [34,39,40].

Moulds, an important microbial factor, substantially influence air quality. Considered main aeroallergens [41-43], they are particularly dangerous for people who suffer from chronic respiratory diseases. Yet remarkably, fungal spores and mycelial fragments are among the most frequent aeroallergens [44-47], with highly allergenic Cladosporium, Alternaria, Penicillium, Aspergillus spores topping the list [48].
According to the Polish Standard PN-86/Z-04111/03 [18], air in Ciechocinek may be classified as uncontaminated with moulds. The vast majority of the air samples from Inowrocław also proved to be uncontaminated. The results obtained in Bochnia and Szczawnica [30,31] indicate a low number of moulds also in outdoor environment. Most importantly, the number of moulds in the contami-

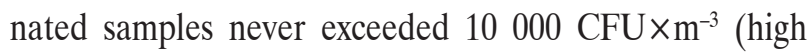
contamination, threatening for the environment). The results obtained by Bugajny et al. [38] indicate much higher contamination in Poznań: the highest recorded number of moulds amounted to $16000 \mathrm{CFU \times m}{ }^{-3}$. In the investigated spa towns the highest numbers of moulds were noted at the sampling sites located in the urban areas. Filipiak et al. [37] have also recorded higher numbers of moulds at sampling sites located in the centre of Poznań. However, the results obtained by Kasprzyk and Worek [49] contradict these observations: they have recorded higher numbers of moulds in the rural than in the urban areas (Rzeszów).

The method of sampling proved to be critical for recovery of microorganisms from bioaerosol. Impaction is at least as efficient as other sampling methods for bioaerosol collection. The most common problem is poor efficiency of collection on the agar surface - smaller particles $(0.5-1 \mu \mathrm{m})$ with insufficient mass, and hence low inertia, are not thrown onto the agar and pass through the air sampler [16]. The AGI-30 impinger and 6-stage Anderson sampler have been shown to be the most efficient collectors of airborne microorganisms (about 5 and 2 times more efficient than a MAS-100) [50,51]. However, collection efficiency amounting to about $50 \%$ is perfectly acceptable if the efficiency is known and the variation in the results is low. Therefore, the Merck MAS-100 microbial air sampler is efficient and convenient for routine evaluation of the outdoor air quality $[52,53]$.

Many authors have emphasised the fact that the number of microoganisms in the air fluctuates and depends on 
many factors such as: climate [5,54], human activity [55], air pollution [56] and the vegetation season [57]. The fluctuations can occur slowly over a long period of time (season) or rapidly within a day [36,58]. The analysis of variance showed that the numbers of bacteria belonging to the majority of bacterial groups depended primarily on the location of the sampling site.

Similar results have been obtained by Bowers et al. [59], who have revealed that these are local sources of contamination that play a major role in shaping the structure of bacterial community in the air, rather than temporary weather changes. Moreover, the results obtained by Ravva et al. [40] and Bowers et al. [59] are similar to the results of the present study and indicate that temperature is the only climate condition which influences bacterial community. The number of bacteria in cities has particularly high spatial variability because microoganisms are often released from the linear emission sources (traffic routes) and area sources (sewage treatment plants).

Seasonal fluctuations in the number of microorganisms are less considerable when compared to more natural environments such as parks or forests [33,60,61]. The results of the present study indicate that moulds were the only microbial group the number of which depended on the season. On the other hand, Brodie et al. [39] state that climate conditions may have a more considerable impact on shaping microbial community in the air comparing to the location. Maron et al. [62] have stated that the number of bacteria in the air in cities shows shortterm (daily, weekly) variability, depending on anthropogenic sources, while long-term variability (seasonal) is caused by climate conditions.

\section{CONCLUSIONS}

Owing to a unique microclimate and low microbiological air contamination in the surroundings of inhalators and recreation areas, Ciechocinek and Inowrocław meet the requirements set for health resorts specializing in treating respiratory diseases. Aerosol formed in the graduation towers has a positive impact on microbiological air quality, which is confirmed by the results indicating substantially lower numbers of microorganisms in the areas located in the vicinity of these open-air inhalatoria.

Building graduation towers is an effective method for the microbiological air quality improvement in spa towns, especially in the immediate vicinity of these structures. The number of microoganisms in the air in both towns depended primarily on the location of the sampling sites; whereas seasonal variability of meteorological conditions played a less significant role.

\section{REFERENCES}

1. Fuzzi S, Andreae MO, Huebert BJ, Kulmala M, Bond TC, Boy M, et al. Critical assessment of the current state of scientific knowledge, terminology, and research needs concerning the role of organic aerosols in the atmosphere, climate, and global change. Atmos Chem Phys. 2006;6:2017-38, http://dx.doi.org/10.5194/acp-6-2017-2006.

2. Despre's V, Huffman AJ, Burrows SM, Hoose C, Safatov AS, Buryak G, et al. Primary biological aerosol particles in the atmosphere: A review. Tellus B. 2012;64:15598, http://dx.doi. org/10.3402/tellusb.v64i0.15598.

3. Polymenakou PN. Atmosphere: A source of pathogenic or beneficial microbes? Atmosphere. 2012;3:87-102, http:// dx.doi.org/10.3390/atmos3010087.

4. Peternel R, Culig J, Hrga I. Atmospheric concentrations of Cladosporium spp. and Alternaria spp. spores in Zagreb (Croatia) and effects of some meteorological factors. Ann Agric Environ Med. 2004;11:303-7.

5. Rossi V, Bugiani R, Giosué S, Natali P. Patterns of airborne conidia of Stemphylium vesicarium, the causal agent of brown spot disease of pears, in relation to weather conditions. Aerobiologia. 2005;21:203-16, http://dx.doi.org/10.1007/s10453005-9002-y. 
6. Griffin DW, Kubilay N, Kocak M, Gray MA, Borden TC, Shinn EA. Airborne desert dust and aeromicrobiology over the Turkish Mediterranean coastline. Atmos Environ. 2007;41:4050-62, http://dx.doi.org/10.1016/j.atmosenv.2007.01.023.

7. Sultan B, Labadi K, Guegan JF, Janicot S. Climate drives the meningitis epidemics onset in West Africa. PLOS Med. 2005; Jan 25, http://dx.doi.org/10.1371/journal. pmed.0020006.

8. Polymenakou PN, Mandalakis M, Tselepides A, Stephanou EG. Particle size distribution of airborne microorganisms and pathogens during an intense African dust event in the Eastern Mediterranean. Environ Health Persp. 2008;116:292-6, http://dx.doi.org/10.1289/ehp.10684.

9. Jie Y, Houjin H, Feng J, Jie X. The role of airborne microbes in school and its impact on asthma, allergy, and respiratory symptoms among school children. Rev Med Microbiol. 2011;22:84-9, http://dx.doi.org/10.1097/ MRM.0b013e32834a449c.

10. Prunk A, Azman J, Frkovic V, Skrobonja A, Muzur A. Physician Albin Eder and his contribution to the development of health resorts in the Northern Adriatic area. Public Health. 2008;122:1131-3, http://dx.doi.org/10.1016/ j.puhe.2007.10.008.

11. Krupa WA. [Conditions necessary for the proper functioning of the spa treatment]. Proceedings of the XVIII Congress of Polish Health Resorts; 2009 Jun 4-7; Muszyna, Poland. Sopot: Izba Gospodarcza "Uzdrowiska Polskie”; 2009. Polish.

12. Gawlak E. [125 years of spa treatment in Inowrocław]. Balneol Pol. 1999;41:47-51. Polish.

13. Kozłowska-Szczęsna T, Krawczyk B, Błażejczyk K. The main features of bioclimatic conditions at Polish health resorts. Geogr Pol. 2004;77:45-61.

14. Kosman M, editor. [Inowrockaw - The capital of the Western Kujawy on background selected European resorts]. Poznań: Adam Mickiewicz University Press; 2010. Polish.

15. Polish Standard PN-89/Z-04008/08. [Air purity protection. Sampling. Atmospheric air sampling for microbiological examination by aspiration and sedimentation method]. Warszawa: Wydawnictwa Normalizacyjne "Alfa"; 1989. Polish.

16. Yao M, Mainelis G. Investigation of cut-off sizes and collection efficiencies of portable microbial samplers. Aerosol Sci Technol. 2006;40:595-606, http://dx.doi. org/10.1080/02786820600729146.

17. Polish Standard PN-86/Z-04111/02. [Air purity protection. Microbiological testings. Determination of the number of bacteria in the atmospheric air (imission) with sampling by aspiration and sedimentation method]. Warszawa: Wydawnictwa Normalizacyjne "Alfa"; 1986. Polish.

18. Polish Standard PN-86/Z-04111/03. [Air purity protection. Microbiological testings. Determination of the number of fungi in the atmospheric air (imission) with sampling by aspiration and sedimentation method]. Warszawa: Wydawnictwa Normalizacyjne "Alfa"; 1986. Polish.

19. Helbin J, Kolarzyk E. [Natural environment advantages in pharmacological treatment support]. Probl Hig Epidemiol. 2005;86:22-6. Polish.

20. Zhilina LP, Dobrodceeva LK. Features of the physical state of schoolchildren before and after a stay at a sanatorium. Human Physiol. 2005;31:142-4, http://dx.doi.org/10.1007/ s10747-005-0039-7.

21. [The Act of 28 July 2005 of spa therapy, spas and spa protected areas and the spa municipalities. J Laws 2005, no. 05.167.1399, item 46, 2 (Sep 21, 2005)]. Polish.

22. Tang JW. The effect of environmental parameters on the survival of airborne infectious agents. J R Soc Interface. 2009;6:S737-46, http://dx.doi.org/10.1098/rsif.2009. 0227.focus.

23. Burkowska A, Donderski W. Bacterial pollution of air in health resort Ciechocinek. Pol J Natur Sci. 2007;22:633-44, http://dx.doi.org/10.2478/v10020-007-0054-z.

24. Burkowska A, Donderski W. Airborne molds in the air of Ciechocinek spa. Pol J Natur Sci. 2008;23:790-800, http:// dx.doi.org/10.2478/v10020-008-0063-6. 
25. Burkowska A, Kalwasińska A, Walczak M. Airborne mesophilic bacteria at the Ciechocinek Health Resort. Pol J Environ Stud. 2012;21:307-12.

26. Burkowska A, Donderski W. [The microbes in the air over the municipal and spa areas of Inowrockaw]. Ekol Tech. 2008;96A:25-8. Polish.

27. Bovallius A, Roffey R, Henningson E. Long-range transmission of bacteria. Ann NY Acad Sci. 1980;353:186-200, http://dx.doi.org/10.1111/j.1749-6632.1980.tb18922.x.

28. Krawiec A. [The curative water in Ciechocinek]. In: Krawiec A, editor. [The hydrogeology of Kujawy and Lower Powiśle]. Toruń: Nicolaus Copernicus University Press; 2005. p. 35-42. Polish.

29. Grzyb J, Bis H, Barabasz W, Frączek K, Chmiel MJ. [Studium upon bacteria occurence in air of Bochnia and Wieliczka Salt Mine chambers]. Acta Agr Silv Ser Silv. 2004;42: 163-76. Polish.

30. Frączek K, Górny RL, Ropek D. Bioaerosols of subterraneotherapy chambers at salt mine health resort. Areobiol. 2013;29:481-93, http://dx.doi.org/10.1007/s10453-0139298-y.

31. Frączek K, Górny RL. Microbial air quality at Szczawnica sanatorium, Poland. Ann Agric Environ Med. 2011;18:63-71.

32. Walczak M, Lalke-Porczyk E, Krawiec A. [Survival of bacteria in geothermal waters]. Techn Poszuk Geolog. 2011;1-2: 413-23. Polish.

33. Fang ZG, Ouyang ZY, Zheng H, Wang XK, Hu LF. Culturable airborne bacteria in outdoor environments in Beijing, China. Microb Ecol. 2007;54:487-96, http:/dx.doi. org/10.1007/s00248-007-9216-3.

34. Fahlgren C, Bratbak G, Sandaa R-A, Thyrhaug R, Zweifel UL. Diversity of airborne bacteria in samples collected using different devices for aerosol collection. Aerobiologia. 2010;27:107-20, http://dx.doi.org/10.1007/s10453-0109181-z.

35. Górny RL. [Biological aerosols - A role of hygienic standards in the protection of environment and health]. Environ Med. 2010;13:41-51. Polish.
36. Abdel Hameed AA, Koder MI, Yuosra S, Osman AM, Ghanem S. Diurnal distribution of airborne bacteria and fungi in the atmosphere of Helwan area, Egypt. Sci Total Environ. 2009;407(24):6217-22, http://dx.doi.org/10.1016/j.scitotenv.2009.08.028.

37. Flipiak M, Piotraszewska-Pająk A, Stryjakowska-Sekulska M, Stach A, Silny W. [Outdoor and indoor air microflora of academic buildings in Poznań]. Postepy Dermatol Alergol. 2004;XXI(3):121-7. Polish.

38. Bugajny A, Knopkiewicz M, Piotraszewska-Pająk A, Sekulska-Stryjakowska M, Stach A, Filipiak M. On the microbiological quality of the outdoor air in Poznań, Poland. Pol J Environ Stud. 2005;14:287-93.

39. Brodie EL, DeSantis TZ, Parker JPM, Zubietta IX, Piceno YM, Andersen GL. Urban aerosols harbor diverse and dynamic bacterial populations. Proc Natl Acad Sci USA. 2007;104:299-304, http://dx.doi.org/10.1073/ pnas.0608255104.

40. Ravva SV, Hernlem BJ, Sarreala CZ, Mandrella RE. Bacterial communities in urban aerosols collected with wettedwall cyclonic samplers and seasonal fluctuations of live and culturable airborne bacteria. J Environ Monit. 2012;14: 473-81, http://dx.doi.org/10.1039/c1em10753d.

41. Green BJ, Tovey ER, Sercombe JK, Blachere FM, Beezhold DH, Schmechel D. Airborne fungal fragments and allergenicity. Med Mycol. 2006;44:245-55, http://dx.doi. org/10.1080/13693780600776308.

42. Bush RK, Portnoy JM, Saxon A, Terr AI, Wood RA. The medical effects of mold exposure. J Allergy Clin Immunol. 2006;117:326-33, http://dx.doi.org/10.1016/j.jaci. 2005.12.001.

43. Iossifova Y, Reponen T, Ryan PH, Levin L, Bernstein DI, Lockey JE, et al. Mold exposure during infancy as a predictor of potential asthma development. Ann Allergy Asthma Immunol. 2009;102:131-7, http://dx.doi.org/10.1016/S10811206(10)60243-8.

44. Womiloju TO, Miller JD, Mayer PM, Brook JR. Methods to determine the biological composition of particulate matter 
collected from outdoor air. Atmos Environ. 2003;37:433544, http://dx.doi.org/10.1016/S1352-2310(03)00577-6.

45. Elbert W, Taylor PE, Andreae MO, Poschl U. Contribution of fungi to primary biogenic aerosols in the atmosphere: wet and dry discharged spores, carbohydrates and inorganic ions. Atmos Chem Phys. 2007;7:4569-88, http://dx.doi. org/10.5194/acp-7-4569-2007.

46. Bauer H, Schueller E, Weinke G, Berger A, Hitzenberger R, Marr IL, et al. Significant contributionss of fungal spores to the organic carbon and to the aerosol mass balance of the urban atmospheric aerosol. Atmos Environ. 2008;42:5542-9, http://dx.doi.org/10.1016/j.atmosenv.2008.03.019.

47. Crawford C, Reponen T, Lee T, Iossifova Y, Levin L, Adhikari A, et al. Temporal and spatial variation of indoor and outdoor airborne fungal spores, pollen, and (1-3)-betad-glucan. Aerobiologia. 2009;25:147-58, http://dx.doi.org/ 10.1007/s10453-009-9120-z.

48. Fröhlich-Nowoisky J, Pickersgill DA, Després VR, Pöschl U. High diversity of fungi in air particulate matter. Proc Natl Acad Sci USA. 2009;106:12814-9, http://dx.doi.org/10.1073/ pnas.0811003106.

49. Kasprzyk I, Worek M. Airborne fungal spores in urban and rural environments in Poland. Aerobiologia. 2006;22: 169-76, http://dx.doi.org/10.1007/s10453-006-9029-8.

50. Research Triangle Institute. Test report of filtration efficiency of bioaerosols in HVAC systems, ASHRAE 52.2 test report. Engineering and Technology Unit Research Triangle Park, NC 27709. 2004

51. Ljungqvist B, Reinmüller B. The Biotest RCS air sampler in unidirectional flow. J Pharm Sci Tech. 1994;48:41-4.

52. Nesa D, Lortholary J, Bouakline A, Bordes M, Chandenier J, Derouin F, et al. Comparative performance of impactor air samplers for quantification of fungal contamination. J Hosp Inf. 2001;47:149-55, http://dx.doi.org/10.1053/ jhin.2000.0883.

53. Whyte W. Collection efficiency of microbial methods used to monitor cleanrooms. Europ J Parent Pharm Sci. 2005;10:3-7.
54. Klarić M, Pepeljnjak S. Year-round aeromycological study in Zagreb area, Croatia. Ann Agric Environ Med. 2006;13:55-64.

55. Mitakakis T, O'Meara T, Tovey E. The effect of sunlight on allergen release from spores of the fungus $\mathrm{Al}$ ternaria. Grana. 2005;42:43-6, http://dx.doi.org/10.1080/ 00173130310008571.

56. Lin W, Li C. Associations of fungal aerosols, air pollutants, and meteorological factors. Aerosol Sci Tech. 2000;32: 359-68, http://dx.doi.org/10.1080/027868200303678.

57. Pepeljnjak S, Šegvić M. Seasonal variability in airborne bacterial communities at a high-elevation site. Aerobiologia. 2003;19:11-9, http://dx.doi.org/10.1023/A: 1022693032075.

58. Maron PA, Lejon DPH, Carvalho E, Bizet K, Lemanceau P, Ranjard L, et al. Assessing genetic structure and diversity of airborne bacterial communities by DNA fingerprinting and $16 \mathrm{~S}$ rDNA clone library. Atmos Environ. 2005;39:3687-95, http://dx.doi.org/10.1016/j.atmosenv. 2005.03.002.

59. Bowers RM, McCubbin IB, Hallar AG, Fierer N. Seasonal variability in airborne bacterial communities at a highelevation site. Atmos Environ. 2012;50:41-9, http://dx.doi. org/10.1016/j.atmosenv.2012.01.005.

60. Harrison RM, Jones AM, Biggins PDE, Pomeroy N, Cox CS, Kidd SP, et al. Climate factors influencing bacterial count in background air samples. Int J Biometeo. 2005;49:167-78, http://dx.doi.org/10.1007/s00484-004-0225-3.

61. Lee AKY, Lau APS, Cheng JYW, Fang M, Chan CK. Source identification analysis for the airborne bacteria and fungi using a biomarker approach. Atmos Environ. 2007;41: 2831-43, http://dx.doi.org/10.1016/j.atmosenv.2006.11.047.

62. Maron PA, Mougel C, Lejon DPH, Carvalho E, Bizet K, Marck G, et al. Temporal variability of airborne bacterial community structure in an urban area. Atmos Environ. 2006;40:8074-80, http://dx.doi.org/10.1016/j.atmosenv. 2006.08.047.

This work is available in Open Access model and licensed under a Creative Commons Attribution-NonCommercial 3.0 Poland License - http://creativecommons.org/ licenses/by-nc/3.0/pl/deed.en. 